\title{
'A Wonderful Lot of Chaps': Observations on New Zealand Army Culture in War Letters from Rod to Molly McLeay, 1940-1942
}

\section{ELIZABETH McLEAY}

It has been argued that, unlike the British, for example, New Zealand soldiers during wartime inhabit a relatively egalitarian army culture. ${ }^{2}$ Those in command are expected both to inform and to listen; they should earn the trust of their subordinates rather than take that trust for granted; and competence is valued over status and formal position. ${ }^{3}$ Given the mistakes that those in command inevitably make, they can retain the respect of their men as long as they hold their confidence. ${ }^{4}$ The existence of egalitarian behavioural norms is the first of four controversial generalisations about the New Zealand Army culture promoted in the historical writings on this subject. ${ }^{5}$ A second proposition overlaps with the first because of its hypothesised contribution to egalitarian beliefs and practices. This is the argument that 'mateship' is a dominant trait, ${ }^{6}$ a characteristic that seems to be marked by camaraderie, an uneasiness about women and a preference for the company of men, ${ }^{7}$ and a tolerance of larrikin behaviour, especially drunkenness. ${ }^{8}$ In this article, I analyse egalitarianism, mateship, and hierarchy as expressed in the letters of a junior officer, Roderick Moscrop McLeay, to his wife, Molly, during his period overseas during World War Two [WWII]. ${ }^{9}$ Thus, I am looking for evidence of the informal rules that shaped the lives of New Zealand soldiers at war: the norms and values that might or might not co-exist within and alongside the formal, hierarchical rules of a command organisation such as the Army.

It has also been proposed that New Zealanders are natural soldiers who accept the need for discipline yet are ready to show initiative, are fit and strong, and who are unusually ready to demonstrate aggression. ${ }^{10}$ Jock Phillips argues that this perception, which he traces back to the Boer War, persisted at least to WWII. ${ }^{11}$ Another generalisation is that the New Zealand Defence Force is 'renowned for its good, often exceptional, junior leadership'. ${ }^{12}$ Although I analyse neither the 'natural soldier' nor the junior leadership attributes here, I discuss perceived leadership qualities as expressed within the McLeay letters. Soldiers' letters can highlight power 
relationships in institutions that are very much the product of their histories and are characterised by hierarchical formations that have altered very little through time. Through the McLeay letters, I focus on the Army's formal and informal organisational rules, and how individuals operate within those rules. As a social scientist, I bring my own approach to the content of the letters and note that the words of respondents 'will always be edited by the researcher and filtered through his or her own theoretical framework'. ${ }^{13}$

One of the values of the letters written by citizen soldiers is in their impressions of an alien culture. However successful their military training, civilian soldiers are outsiders who happen to find themselves temporarily inside the institution of the armed forces. Their futures, they hope, are in civilian life. Not that there is any sign that Rod McLeay saw himself as commenting on aspects such as power, hierarchy and fraternity. Rather, he was simply writing to his wife, communicating across the oceans, telling her about what he thought would interest her and how he felt about what was happening to him. He told her about training exercises, training courses, marches, his travels and adventures on leave from the camps, his health, the gifts he was buying for her, sleep and the lack of it, the locals he met, the people they both knew, the heat and the cold, the dust and the sand, the flies, fleas and rats, his food parcels, and the food in camp and on leave. (There is a great deal about food.) Rod McLeay spoke of the battles in which he was involved, but cautiously: the need for censorship, plus his own reticence and desire not to upset his wife, prevailed. He also frequently referred to the letters he had - or had not - received..$^{14}$ Above all else, Rod's letters are about people.

Although a civilian who had been working in business before the war, Rod McLeay was not entirely a participant in a strange culture, because, until he finally managed (through military pressure) to get his employer to release him for active service, he had been a member of the Territorial Army. Perhaps his secondary school experience at Waitaki Boys' High School, where he boarded for three years and where he became a crack shot, led him to join. Rod never had any intention of becoming a permanent member of the armed forces, but he knew more or less what he was in for when he enlisted.

I begin by briefly outlining Rod McLeay's social background and his military service, because these are germane to his view of his world. Second, I examine his social life, looking for evidence of his relationships with others in the army, below and above his own rank. Third, I explore Rod's perceptions of hierarchy and authority, as revealed by his letters. My fourth theme concerns the writer's views on his role as a leader, not only in terms of how he saw his relationships with his men but also his thoughts on his own career and subsequent promotion. Finally, I attempt to relate the 
content of the letters to the arguments about the posited egalitarianism and mateship of the New Zealand Army during WWII.

\section{Rod McLeay: background, career, and letters}

Rod McLeay, the eldest of six children, was born on 23 February 1912. He grew up in Napier, where his father was managing director of Richardson and Company, a coastal shipping firm. Kenneth McLeay was a prominent member of the Napier community. Indeed, when Rod had not received any letters after first arriving in Egypt, he decided to take action, writing to Molly, '[N]one of the H.B. [Hawke's Bay] Officers have received any Air Mail or sea mail, with the exception of Capt. M., who yesterday received seven, all bearing the same date of postage on the envelope. It is obvious that the Postal Officials in H.B. have been holding the mail for some unknown reason, and so within a few days I will be writing to Dad to see if he can get anything done through the local R.S.A. or Chamber of Commerce'. ${ }^{15}$ The family was relatively affluent: Rod, and his next brother, named Kenneth, were sent to board at Waitaki Boys' High; the three daughters were educated at private boarding schools; and the family had a live-in maid until after the war. Rod left school after three years and joined the Vacuum Oil Company in Wellington, where he worked as a clerk, mainly in accounting. Rod and Molly Treneman married in November 1938. ${ }^{16}$ In March 1940 Rod entered Trentham Camp.

While in the Territorials, Rod had been promoted to Second Lieutenant, and he was a Lieutenant by the time he entered camp. As is well known, during the first few years of WWII, the Second New Zealand Expeditionary Force's officer corps was drawn from the small regular Army and from those who had served in the Territorials. The officers also tended to be appointed from amongst the "educated middle class'. ${ }^{17}$ On 27 September 1940 Rod embarked from Wellington on the Mauritania with the Third Echelon as a member of 25 Battalion, part of 6th Brigade. He wrote to Molly, 'As you know it was a grey morning and matched my mood. ${ }^{18}$

Initially, Rod was in charge of 15 Platoon, of the C (rifle) Company commanded by Major C.J. Williams. ${ }^{19}$ After training in Egypt, mainly in Maadi Camp (the New Zealand base camp in Egypt), he fought in the abortive Greek campaign in March and April 1941, during which, in James Belich's words, 'hopelessly inadequate Allied forces were predictably hustled out of Greece in a mere three weeks'. ${ }^{20}$ In September 1941 he became Temporary Captain of 'A' Company, initially second-in-command and subsequently Company Commander. At times he acted as a staff captain in headquarters and also as adjutant. That he was second-in-command of his company during the November 1941 Operation Crusader offensive into Libya might have saved Rod's life. It was Battalion policy to hold back 
the second-in-command officers (and Divisional policy to hold back about $20 \%$ of its men), who were initially left out of battle. ${ }^{21}$ On 23 November 1941, when 6th Brigade attacked Point 175 (near Sidi Rezegh), 25 Battalion lost 100 men - the greatest number in a New Zealand action in WWII. ${ }^{22}$ Rod was sent to the frontline during the last days of this offensive. From 4 February 1942 Rod's captaincy was substantive; and he was in Syria with the rest of the 6th Brigade, serving on garrison duties.

After several complaints in his letters that 'his 'tummy had been out of order', that he was 'losing his tucker', and that he thought that it was 'due to the sand I have been swallowing, ${ }^{23}$ Rod was hospitalised in April 1942 (bringing the letters in the family's possession to an end). After having major surgery and recuperating in Cairo for some months, he returned to New Zealand, having been promoted to Major in May 1942. Rod worked in Wellington in Army Headquarters until the end of the war, when he returned to civilian life. He became very much a family man, although he kept up some individual wartime friendships, including with his former batman. He valued his military medals but took no further interest in the army or his war. He had little respect for the local branches of the RSA with (he thought) its drinking culture, until the last few years of his life, when he met up with some former servicemen whose friendships he valued. Rod died on 22 May 2006.

Between his departure from Wellington and 27 April 1942, the date of the last letter in existence, this young officer regularly wrote to Molly. She typed the letters so that she could send one copy to her husband's parents and keep two in the family records. She censored them a little, omitting only the very personal words to her. ${ }^{24}$ Despite this, and despite the fact that Rod must have known that his letters were reaching a wider audience than just his wife, the letters are a frank expression of longing for home, his family, New Zealand, and Molly: 'Here I am again with a few minutes to spare with you .... ${ }^{25}$ The letters contain lively and often funny descriptions of army life and his trips while on leave. Furthermore, they include much of interest concerning the army culture, making a small contribution to the literature on this subject. As Deborah Montgomerie observes, letters 'remind us of the fragility of human relationships and the way in which historical knowledge is built on fragmentary and scattered sources'. ${ }^{26}$

In the next section I explore Rod's social relationships, seeking insights into the army culture, particularly the extent to which it was hierarchical or egalitarian.

\section{Relaxation and leave: social relationships}

With whom did Rod spend his non-working hours? Did Rod tour, party, or drink with the men he led? Of course, the outstanding social leveller was 
organised sport, and Rod, as did others, played rugby with all ranks. He also socialised with those he commanded, but not frequently. On one of those occasions he shared his birthday cake, baked and posted by Molly, and he wrote: 'The cake was wonderful and the boys of the Platoon want to send on their thanks, as they all participated and enjoyed it immensely. ${ }^{27}$ Rod had similarly shared his Christmas cake during the previous Christmas. ${ }^{28}$ On another occasion, 'the lads in my platoon [his former one] invited me along and we had a great time talking about the past. They didn't mind admitting all the things they managed to put across me when I was in Command. As one of them said "now that" you have left us, we can unburden our "consciences" (I like that - no one in that platoon had a conscience - or even knew the correct interpretation of the word). ${ }^{29}$

Rod took a great deal of pleasure from the company of his men. ${ }^{30}$ There is a moving and amusing section in his letters that describes how 'miserable' he was during his first Christmas overseas. He and others decided to cheer themselves up 'with a few spots' by invading the Sergeants' Mess: 'This we did, with dire results, not leaving until 2 a.m.' He continued:

I reached my tent and found pinned to my towel which hangs over my bed, a huge H.B. [Hawkes Bay] Black and White football stocking, containing a small gift from every man in my platoon, together with a note signed by each one of them. These kind thoughts from my men took all my misery away and I can assure you that I was very proud of the fact that they had thought of me at this time. Next morning (Xmas Day) when parading for Church Service I could see that they were just waiting for me to say 'thank you' but I didn't say a word, instead, I waited until after the parade, and before dismissing them told them there would be a parade outside the N.A.A.F.I. [Navy Army Air Force Institute] at 4.30. When 4.30 arrived I duly marched them in and bought each one of them a bottle of beer and then thanked them. I think they appreciated my action. ${ }^{31}$

The poem with its list of signatures was enclosed with the letter, and Molly was to keep it, 'as I treasure it very much'. ${ }^{32}$ At New Year, he had no heart for getting 'merry', and after 'visiting my boys and having a beer with them I went to bed at 10.30 , ${ }^{33}$

The above examples provide evidence of a certain degree of fraternisation between men and officer, but these episodes were almost entirely occasions when certain events required noting, such as celebrating Christmas or having a reunion with a former platoon or company. In general, officers consorted with other officers rather than with the men. Of course, the army encouraged stratified socialising, with messes and sleeping accommodation separated by rank. Thus, it is hardly surprising that Rod's leisure time was generally 
spent with two main groups, other officers and pre-war friends. There are very many instances in the letters where Rod related how he socialised and toured with various majors, captains, the 'Doc' and the 'Padre': going to films, restaurants, nightclubs and private homes in Cairo, travelling south in Egypt to see the monuments, and visiting Palestine. Sometimes work led to interesting social occasions. He described doing guard duty at 'a certain aerodrome' and wrote: 'Our first appearance in the Mess nearly took our breaths away - it is a wonderful place - more like a hotel - and as for hospitality, I have never struck anything like it before. As soon as we appeared a pewter tankard of ale was placed before each of us, and I have come to the conclusion that the Air Force officers don't know the meaning of that little word "no". Their table is first-class and makes our own Battalion table just like a barn feed. ${ }^{34}$ Given that the New Zealand forces were not known to be badly fed, perhaps this comment not only mocked the British but also was an observation about the relative equality of the New Zealand messes.

What might be surprising was the extent to which, even as a relatively lowly lieutenant - second-to-bottom of the commissioned ranks - Rod consorted with officers who were very much senior to him. In a letter written in late 1940, he confessed to Molly that, although attending 'a very stiff course in the Small Arms School', he had been 'on the binge' with the instructor, although 'all this trouble was quite accidental'. As the two of them were leaving the mess to go to the pictures in Cairo, Colonel Wilder (25 Battalion) invited them to accompany him in his car to the Maadi Club, and then go to Cairo. After having 'four or five spots', 'our really "big shot" joined us - our Brigadier, Colonel Barraclough in Command of the Brigade [6th Brigade]'. ${ }^{35}$ After more 'shouts', they went off to a French restaurant and then to a film through which, unsurprisingly, Rod dozed. He added dryly: 'Sunday dawned with a nasty headache.' On other occasions described in the letters, commanding officers lent their cars or offered lifts to their more junior colleagues, helping with their social jaunts. At the end of 1941, Rod mentioned that, among others, he had visited Colonel McNaught (Commanding Officer of 25 Battalion) in hospital. The colonel had received three wounds in the Libyan action, Operation Crusader, at the end of $1941 .{ }^{36}$ Friendly relationships clearly existed amongst the commissioned men throughout the ranks.

The other men with whom Rod socialised were those he knew from home, mainly from Hawkes Bay and Wellington. Place - geographical origins anchored the men's allegiances to home and to each other, a factor that has often been commented on in the war literature. ${ }^{37}$ The New Zealand battalions, as in many other countries, were regionally based. ${ }^{38}$ Twenty-five Battalion was drawn from the Wellington, Hawkes Bay and Taranaki provinces. ${ }^{39}$ 
Letters from other soldiers serving overseas affirm the importance of the personal links to home. Montgomerie quotes from the letter of Bob Wilson, who wrote: 'I am always on the lookout for the home boys. ${ }^{40}$

Although he made some friends after leaving New Zealand, Rod's letters were replete with references to men he had known at home, especially from Hawke's Bay. Many of these friends had been made through the Heretaunga Tramping Club, which Rod had joined after meeting Molly. ${ }^{41}$ What could be more natural, after all, than peopling letters with those the writer and recipient have in common? Messages went back and forth: 'I saw Ed. yesterday. Will you let [his family] know that he looks really well, and is now in a safe job in Base on the instructive staff',42 'Doug is looking very pale after his sojourn in Hospital, but the brisk life he will be living here should tone him up wonderfully. Mrs C. will no doubt be interested to learn that Les. is looking extremely fit, so perhaps you could ring them sometimes'; 'Incidentally, you can tell Mrs M. that I am proud to have John in my Platoon as he is an excellent lad - very keen, and really knows his work. ${ }^{44}$ In this way, Rod drew his wife into his army relationships and, conversely, through Molly cemented his relationships with others, including those men serving under him. Rank mattered little compared with established circles of friendship and acquaintanceship, as the following quotation shows: 'Les C. is now with the Battalion and is a Cpl. in my old Platoon. Last night he came to visit Doug D. and me, and I entertained them to supper in my dug-out. What a lot of "magging" went on, it was just like a mothers' meeting during a Church social. It was grand while it lasted, but we are all very homesick .... . ${ }^{45}$

Rod, for one, took a great deal of pleasure in meeting up with the people he knew, but most of all he wanted to see his younger brother, Ken. They met up in February 1941, and 'it was a real thrill to see him again'. ${ }^{46}$ They shared a tin of Molly's shortbread and toured Cairo together. Rod reported that Ken was well after the Greek campaign, worried about him when Ken was evacuated to Crete (while Rod returned to Egypt), announced that Ken had been released from hospital where he had been ill after the evacuation from Crete, saw him again in July 1941, pronounced his pleasure in Ken's promotion to Sergeant in September, and heard about Ken's Military Medal, not from Ken but from Molly, in October. Late in October 1941, the two brothers got together again: 'Yesterday, my third attempt, I at last contacted Ken and he is looking very fit and well. We had an enjoyable afternoon together and on Sunday he is going to spend the day with me. Like me, he is very homesick. Neither of us have the ability for making friends readily and so you can imagine what a treat it is for both of us to catch up with each other. ${ }^{47}$ This was the last time they would meet, for Ken was killed 
in early December: ${ }^{48}$ 'It has been a very bitter blow and I dread to think of the sorrow it will bring at home. ${ }^{49}$

Leaving aside the connections with home, both kith and kin, Rod's letters illustrated some elasticity in his social relationships, although the boundaries of hierarchy were certainly of predominant significance. What of his attitudes towards authority, another indication of the characteristics of army culture?

\section{Attitudes to authority}

Rod was not deferential towards his superiors: 'On Friday we paraded in Hades Bowl in the mid-day heat for an inspection by a gentleman called $\mathrm{Mr}$ X. It turned out to be Anthony Eden of all people. ${ }^{50}$ Indeed, he had little patience with parading as such. And although he spent some of his free time with his superior officers, mainly from within his own battalion, he was not averse to criticising army decisions. When he found that the men would be sent out on a route march on Boxing Day he exclaimed that "just because a man is in the King's uniform and going to fight for his country is no way to treat him ... . The chaps get a hard enough time of it at present without rubbing it in. Unfortunately, that seems to be the Army attitude, and I haven't any say in the matter.' ${ }^{51}$

There was the occasion when, in command of 80 men, he went out to the Range for a training exercise: 'Our transport failed to put in an appearance until 4.30 - once again it was 6 o'clock before we arrived back at Helwan. Fancy having to drive 22 miles to fire a Bren Gun when there is thousands of miles of sand just outside the tent door. ${ }^{52}$ Shortly afterwards his Brigade carried out a mock attack: ' . . . a poor show. Unfortunately the Senior Officers do not seem to realize that the men must know what is going on before they can carry out the job thoroughly. As it was, the preliminaries were far too hurried .... ${ }^{53}$ Rod enjoyed putting at least one senior officer at a disadvantage. After an episode described below (when the men ate all the food, leaving none for the officers), the Major marched half the Company back, while Rod took the remainder, marching by compass. Rod wrote gleefully: 'Poor old Major! He lost himself, and I arrived back with the men, right on the objective. I don't think he's too pleased that a junior officer managed to put one across him. ${ }^{54}$ And sometimes he just laughed at the Army, as when in a lecture on security they were all told " "do not talk in your sleep - there may be a Gerry (German) under the bed!", 55

Much more seriously, Rod was scathing about events during the Greek campaign, especially during the retreat when, at Molos on 23 and 24 April 1941, 6th Brigade was attacked by the Germans with machinegun fire, dive-bombing and strafing. The Brigade was outflanked by the advancing Germans. ${ }^{56}$ Twenty-five Battalion, with 4, 5 and 6 Field Regiments and 
the Royal Horse Artillery, managed to halt the attack and then, with 24 Battalion, withdrew. Just a few years before his death, Rod rediscovered his notes made immediately after the engagement at Molos, sent home to Molly and placed in his army book after the war. Among other criticisms of that engagement, he wrote that there was a lack of information that applied 'equally about our own troops and that of the enemy'. ${ }^{57}$ Because they were not advised of the routes, 'a large percentage of the casualties in my platoon' were caused by their own troops 'mistaking the withdrawing troops for Germans'. The threat of parachute troops and fifth columnists at Ellissian and Molos was over-emphasised, affecting his 'meeker men, not only in my own platoon'; personnel were untrained; and, while his own company did not fire on enemy aircraft, thus not revealing their positions, other companies did so and were bombed and gunned..$^{58}$

After the retreat from Greece, Rod wrote a formal letter of complaint about the behaviour of an officer who, he felt, was responsible for unnecessary deaths. He was informed that his action was highly unusual. However, this officer was later removed, and Rod was drawn aside and quietly told that his letter had had its effect. ${ }^{59}$ Discussing the Greek campaign generally, John McLeod writes that some officers at quite senior levels demonstrated an inability to cope with the pressures of modern warfare.$^{60}$ Officer incompetence undoubtedly led to lack of confidence, and inexperience equally undoubtedly played its part. ${ }^{61}$ Rod's non-deferential and outspoken behaviour reveals, I believe, a culture that tolerated, at least to some extent, independent and critical thinking about leadership. How then did he perceive his own role as a junior officer?

\section{Perceptions of the leadership role}

\section{Rod and his chaps: authority and fraternisation}

Rod was probably no different from many other officers in that he accepted a certain amount of irregular behaviour from his men. Speaking of novels and informal writings on war, Phillips writes: 'What is significant is the open acceptance and pride in that larrikin mateship that New Zealand society had previously worked so hard to repress and not admit as part of the public male identity. ${ }^{92}$

Excesses of alcohol were permissible. When acting as orderly officer, Rod "had a great time keeping the lads in order in the N.A.A.F.I. bar they seemed intent on smashing everything they could lay their hands on, including beer mugs and windows! ${ }^{163}$ Rod also tolerantly describes supporting drunken men back to barracks. Pete Connor writes: 'By providing a public discourse that portrayed alcohol as an important part of life to both officers and ranks, an appearance of common ground was established between officials and men and this helped build bridges between the two groups 
despite the diverse backgrounds of the hierarchical army organization. ${ }^{64}$ There were limits to Rod's patience with drunken soldiers, however: 'Coming home with the Padre, a chap got on the Camp bus very much worse for wear and commenced using disgusting language, at the same time refusing to pay his fare. Unfortunately for him he didn't see me until I arose with a Winston Churchill look on my face, and after I was finished with the blighter I can assure you he was very nearly sober!' ${ }^{65}$ Some sorts of behaviour challenged Rod's own moral code and conservative upbringing.

Thieving was also tolerated by Rod, even encouraged. ${ }^{66}$ Rod proudly described his own skill in designing camp ovens from purloined elements, even sending home drawings of his inventions. When his company was requisitioned to unload ships, his men worked hard, and he commented: 'The lads had all of Dad's water-side workers licked.' But he chose not to notice the looting that took place, referring to the Military Police concern at the 'mysterious disappearance' of quantities of American beer and exclaiming: 'I can't possibly imagine how it disappeared every time my back was turned. Can you? Believe me, it was grand beer. ${ }^{97}$

Despite the collaboration with thieving soldiers that this last story tells, there were distinct boundaries between officers and men. A postwar New Zealand Army publication of 1949 noted that, although a young officer can be interested in the affairs of his men, 'he cannot indulge in familiarity and retain full control. Mere popularity is not a substitute for respect'. ${ }^{68}$ From the evidence of the letters, at least, Rod seemed to understand this instinctively. While tolerating some larrikinism, he retained a degree of distance from the men and was certainly at pains to preserve his authority and reputation. He described how one night he became lost between his post and the Mess (a mile from each other). He was 'completely fogged, although I could hear my patrols moving around. Of course you will understand that I couldn't possibly yell out to them for fear of the "raspberry". Eventually I landed at my destination and ticked off the patrols for not challenging me!!! It saved my face. ${ }^{69}$

Being in command, even at a relatively lowly level, meant taking responsibility for people's safety and wellbeing, involving an element of paternalism. He and another officer took the Company for one of many route marches, 'and the boys had a wonderful time' and were rapidly becoming very fit: 'Unfortunately, dysentery is playing havoc with them at present, due to two factors - flies and carelessness. ${ }^{70}$ After being in Greece for some days, Rod reported his pleasure that 'my Platoon is still intact'. He added: 'The boys have been behaving wonderfully in face of it all, and up to the time of their arrival here, had had no sleep for three days (and nights).' But later, completing that letter, he wrote: 'Am now in safety, back in Egypt after going thru' Hell. Only 12 of my 38 lads left. ${ }^{, 71}$ His next letter described the 
battle of Molos: "Actually "C" Company took the whole brunt of the attack upon our unit hence the large casualties, 26 in my own platoon alone.' A graphic description of what happened in the attack and the retreat followed, including how he 'patched up two lads' who had been wounded and helped them to shelter and then handed his Platoon over to his sergeant so that he could crawl back and find 'some of the lads' who had been hit. He could not find them. ${ }^{72}$ In fact, most were captured rather than killed, as he later learned and reported to Molly.

A number of other comments and episodes illustrate Rod's attitude to his men. As an officer, there were certain tasks he had to undertake, conforming to regulations and expectations. For example, he had to censor letters, 'a terrible job ... that I heartily loathe' ${ }^{73}$ Another unwelcome but unexpected duty was being required to defend a soldier at a court martial: 'Why me? I'm not a lawyer and the case is rather serious, so last night and to-day has been spent in legal research so I trust I'm able to "put over" my "stuff" for the poor blighter tomorrow. Unfortunately, his case is so serious that he is going for a long trip to gaol, so all I can hope to do is to shorten the sentence a bit.' However, he ended this story on a more positive note with the question, "Who says that Army life is monotonous?' ${ }^{4}$

There were even sadder duties that came with the job. After the Greek expedition, he said: 'It is hard for me to write to the next of kin of my missing lads as I don't know how many of them were killed or how many were taken prisoner, and one can't very well write and bolster up the hopes of their loved ones, only to write at a later date and blow their hopes to bits. ${ }^{75}$ After the action in Libya in late 1941, when 25 Battalion had so many fatalities and wounded men, he anguished: 'It has been a frightful job going the rounds of the different hospitals to see the chaps and have a talk with them. I know how they appreciate it but I'm very glad they don't know how I hate doing it. 76

Rod plainly had pride in his men, taking pleasure in little as well as big things. He described a dugout from their last position (in Greece) and wished he could send Molly a photo of it: 'a masterpiece. Two of the lads volunteered to dig it for me and [it] has proved to be a comfortable resting place ... . Unfortunately we had to leave that place in a h--1 of a hurry so I suppose a smelly Hun is occupying it now. ${ }^{, 77}$ After the Greek campaign he wrote: 'I was very pleased to see in the last lot of general Orders that three of my men who were left behind in Greece have been mentioned in dispatches, Larry B., Jack H., and Bill K. (now back after escaping). I thought that my recommendations for awards had gone astray, but apparently not, and it is a source of pride to me to realize that their services were appreciated. ${ }^{78}$ 
At times, work involved having a good time with the men. He wrote about going out on a 'simple stunt' when the men had to cook their own meals: 'I managed to snaffle a few old petrol tins and made a Platoon fireplace on which we boiled eggs and made toast. The lads thought it was wonderful.' ${ }^{79}$ Later, the officers went off to a camp, only to return to discover that 'the hungry young blighters had eaten everything within sight', leaving the officers without their meal: 'My chaps told me with great glee when they discovered what had happened that the stew was the best they had ever tasted!" ${ }^{80}$ And he described his Platoon in C Company thus: 'There is no getting away from the fact that I have a wonderful lot of chaps under me. To see them this morning, straight after a nights duty, and playing about like so many spring lambs, and me at times just about helpless with laughter. Then to take them out on a tactical exercise and see them stalking one another, just as they did when they were kids playing cowboys and Indians, only they enjoy it much more now than when younger. ${ }^{, 81}$ Rod took much pleasure in receiving expressions of trust and liking from his men, exclaiming on returning from a course: 'What a thrill I received when the boys first saw me - they cheered like a mob of kids, so I consider that it isn't so bad coming back after all. ${ }^{82}$

As has been observed, while overall battalion esprit de corps has to be fostered by the commanding officer and the company commanders, the noncommissioned and junior officers have to maintain 'smallgroup cohesion'. ${ }^{83}$ The above examples show how Rod McLeay saw his responsibilities as a junior leader, including maintaining the cohesion and morale of the men under his command, but how did he regard his particular position as a lieutenant, including his attitudes to promotion and the way in which the Army treated him?

\section{Perceptions of promotion}

Individuals' views on how they fit into an institution, and how institutional rules affect them, can be uncovered by analysing how they perceive their futures, including the possibility of promotion.

Apart from enjoying the privileges of being an officer on shipboard and in camp, Rod made no comment in his early letters about any expectations of moving up the military ranks. However, he was pleased to be sent on a range of courses during his months in Egypt. No doubt they were more interesting than the usual training exercises. In early November 1940, he described 'attending a very stiff course at the Small Arms School, working all day and swotting at nights' (and much partying, according to the letters). ${ }^{84}$ A couple of months later, Rod spoke of his hopes of attending a month-long course at the Middle East Tactical School in Abassia. ${ }^{85}$ In December 1940 he reported that he would indeed be going on that course and was 'looking 
forward to it immensely'. Early in the New Year, after a church parade, 'the Colonel collected those officers who are going to the Tactical Course ... and gave them a fatherly chat, explaining that although he expected them to do our best, he would not be disappointed if we did not obtain a "Distinguished Pass"'. Off to the new camp, where 'our quarters are excellent and the table tip-top', but Rod expressed his disappointment that the course had been reduced from five to three weeks. ${ }^{86} \mathrm{He}$ went on to describe the course, his wonderful 'native servant batman', and his social life, which included a formal dinner in the home of a British minister (politician), all in some detail. He found the course itself fairly easy, although at one stage he said that one of his reports had commented that he was " "still shy"!!"87 He wrote that he had done 'rather well', topping the School in a number of subjects: 'Some "skite" you've got for a husband. ${ }^{88}$ In mid-February, Rod attended a further course on 'Field Works Tuition', this time only one week long, held in camp. Unfortunately, the lectures were 'monotonous', and he reported that he had already learned the material. ${ }^{89}$

On 9 March 1941, Rod informed his wife that he had been acting as second-in-command of the Company and was 'feeling extremely important'. This was his way of poking fun at his own ambitions - the first time we have an overt indication that he harboured any at all. After the Greek campaign, he acted as the Battalion's Adjutant while guarding a prisoner of war camp and then again acted for a period as second-in-command of his company. On 13 July 1941, writing from Ismailia, Rod said that his Major had gone away for a week, and thus he was Company Commander and trusted that he would 'make a good job of things'. He continued: 'I am wondering what is ahead of me as I have been relieved of my platoon and am wondering if there is a special job ahead of me. Of course this may possibly be a temporary measure only, but still gives me cause to think. I have been advised that I will not be relieving the adjutant owing to taking over "C" Co. for the week. Needless to say I am rather disappointed but it can't be helped. ${ }^{90}$ The following month he was instructed to report to an artillery unit 'to learn something of the artillery weapons and tactics' ${ }^{91} \mathrm{He}$ had 'a wonderful time' and 'learned a lot' that 'should prove very useful to me in the future'. ${ }^{92}$ Then he was back to being second-in-command of C Company under his friend, Captain McBride: '... and we are both as pleased as Punch. There is a slight possibility that my Captaincy will come along shortly, but I think I will miss by one!' ${ }^{93}$ In his next letter home, however, Rod wrote:

This morning Colonel (now Brigadier) Wilder sent for me and told me the good news that I was to receive my Captaincy, and was most embarrassingly flattering in his remarks about my record since leaving New Zealand through Greece. Tomorrow morning I take over as second 
in command of "A" Coy. with Capt. Roberts as my O.C. and I think that we will work together pretty well. I may add that this promotion is very unexpected as I have superseded three officers who were really senior to me, and as the Colonel stated, it is the first time in the history of the Battalion that such a thing has happened. So I am most fortunate. ${ }^{94}$

In the same letter he recounted how he was the guest of 'the men in my Platoon who returned from Greece and had a wonderful time with them', a party that became a farewell. He also recorded: 'I am having the time of my life re-organizing and running the company as I want it!!! There is a great crowd of fellows here and I feel that I will be very happy with them.' On 15 September he reported that his new job was going 'satisfactorily' and that he was 'rapidly settling down to a job in which I am my own Boss! ${ }^{95}$ In October he said that he had been told to go up to the front line: "... to have a "look see" and learn what I can for three days. Once again I am somewhat lucky as although according to all Army Regulations I am classified as the junior Coy. 2 i.c. I will be the first 2 i.c. in the Bn. to have the privilege of going up. It does look as if I will have to take a larger size in hats as you have many times remarked in your letters!!!'96 Not that Rod was always as confident as he sometimes seemed. When Captain Roberts went into hospital a couple of weeks later, he suddenly found that he had to command the Company during a three-day exercise, and 'you can imagine what state of mind I was in', a responsibility that was extended beyond that period, so he had 'all the worries of the world on my shoulders'. There was still no word about his promotion, 'but I understand that the Colonel has written to the Military Secretary asking him to speed it up'. ${ }^{97}$

Rod had to wait for some time for his promotion to become substantive, because he had indeed been promoted ahead of others. ${ }^{98}$ However, he became acting staff captain of an infantry brigade with different but 'extremely interesting' work, although he was 'darned if I can get used to' lieutenants calling him 'Sir'. ${ }^{99}$ The loss of the adjutant in the Libyan campaign meant that he took the adjutant's place until being put in command of A Company. ${ }^{100} \mathrm{~A}$ couple of months later, he said that it should not be long before his captaincy was made permanent: 'as I am next on the list. After that I suppose the next thing to look for will be my Majority!!! In that case I will have to send you a crown. ${ }^{101}$ Before being posted to Syria, Rod's captaincy was finally made permanent: "[T]hat meant that the "Powers that be" can only take it off me by Court Martial!' This was a relief because 'if I had been unlucky enough to receive a wound and had been sent to Hospital I would have reverted to the rank of Lieutenant [a point that had been made in an earlier letter], so that is what a grateful army thinks of the ones who work for it' ${ }^{\prime}{ }^{102} \mathrm{He}$ was back with C Company by the end of April, now in his different role, in command and 'thus realizing an ambition I have always 
had'. ${ }^{103}$ There is no record of what Rod felt when indeed he achieved his 'Majority' in May 1942. By then he had been hospitalised, and the letters from his sickbed were neither kept nor typed.

So here we have letters from a soldier who knew his own worth and could anticipate and take pleasure in his promotion, at least while writing to his wife. He (and she) also made fun of his ambitions. At the same time, Rod chafed at the slowness of the process and the rules of seniority. Hierarchy was accepted, but not uncritically. There is no hint of deference here, fitting the 'relatively egalitarian' generalisation about New Zealanders at war. However, we cannot discount Rod's personality and social background: while an intensely private person and indeed quite shy, he had the self-assurance acquired from his education and family background.

\section{The McLeay letters: hierarchy and leadership; egalitarianism and mateship}

Armies are command organisations, based on strict disciplinary rules and hierarchically defined formal roles. Nevertheless, effective military leadership, like that in other formal institutions, is founded upon leaders' relationships with followers. Followers - the men and women in the ranks - have to be persuaded that it is in their own interests and, more significantly, in the interests of the army and the country, to follow the commands of their leaders. Like political leaders, military leaders at all levels have to inform and persuade and to lead by example, but unlike political leaders (except in certain circumstances), military leaders have mandatory powers over those they command. The McLeay letters show that the New Zealand Army at war was a hierarchical organisation with clear distinctions among the various ranks. Function, goals, and tradition all contributed to the hierarchical power arrangements.

Nonetheless, armies, especially civilian-based armies, are the creatures of their wider environments as well as being shaped by their own histories. Informal organisational norms and values matter in addition to the formal rules. The New Zealand Army during WWII, as conveyed in the McLeay letters, displayed elements of the wider egalitarian democratic culture that so many observers have noted existed in New Zealand from its origins onwards. New Zealand has never been an equal society, but there has been a pronounced belief in egalitarian principles. Whether that meant that the New Zealand Army between 1939 and 1945 was more egalitarian than those of other countries is of course unanswerable, although it is very probable that this was the case. There is survey evidence from the 1980s and 1990s that military forces in different countries exhibit markedly different cultures and that these institutional cultures tend to reflect national characteristics: for example, 'relatively operational matters like military discipline are 
considerably influenced by military culture or even the culture of society at large'. ${ }^{104}$ Without full comparative historical analysis, we cannot tell just how the New Zealand Army during WWII differed from others, if at all. However, there are signs that the egalitarian norms evident in the wider New Zealand culture were transferred to the military arena. The New Zealand armed forces, from the evidence of the letters here and elsewhere, tolerated a degree of quite open criticism from within its ranks, the sense that leaders had to earn respect through performance rather than take that respect for granted. As Phillips points out, New Zealanders have been characterised as exhibiting individual independence, cross-fraternisation, and lacking deference towards higher officers. ${ }^{105}$

Within the McLeay letters, a further behavioural norm emerged: soldiers expected to be fully informed by their superiors. Effective leadership in armies as well as elsewhere largely relies on the exchange of sufficient information between leaders and the led, and so leadership depends on good vertical, as well as horizontal, communications. This instrumental reason for officers communicating with the ranks and for senior officers communicating with junior officers, seemed to have been reinforced by the fairness norm in the New Zealand army, as indicated in the McLeay letters. If the fairness norm is placed alongside other cultural traits, especially the relative absence of deference and the practice of treating people as of equal worth, then the New Zealand Army in WWII could be said to exhibit a degree of egalitarianism. But the McLeay letters also suggest that hierarchy, bolstered by the command power structure, tradition and New Zealand class differences, mattered a great deal. ${ }^{106}$ The New Zealand forces were not 'immune to the class problem'. 107

So the McLeay letters add another small piece of evidence to the mixed verdict that, although there were signs of egalitarian norms and values, hierarchy remained of vital importance in the New Zealand army during wartime. Was there an associated culture of 'mateship'? From the literature on this topic, as briefly explained earlier, the recipe for 'mateship' seems to have three ingredients: camaraderie amongst men, the preference for men's company over that of (mainly absent) women; and larrikinism - tolerance of wild and boisterous male behaviour.

Mateship in the sense of comradeship refers, of course, to the close relationships that develop among serving men who share hardship and privation. It has been posited that these close relationships were present amongst New Zealand (and Australian) soldiers. ${ }^{108}$ Phillips argues that this was a myth that was confirmed by the events of World War One. ${ }^{109}$ Montgomerie, however, perceptively points out: 'Mateship is another idea at the heart of our depictions of war. In the post-war period, war was seen as having few redeeming qualities apart from the camaraderie it created between 
men.' After speculating why this belief may have developed, Montgomerie asks 'how far should we go in emphasizing the bonds between men in war?' ${ }^{110}$

Perhaps camaraderie should not be seen as anything more than group cohesion, a necessary ingredient for any successful army. ${ }^{111}$ There are obviously very strong incentives within an army at war for soldiers to get on well together, since their lives depend on one another, as pointed out in a study of Australian infantry in the Pacific. Gavin Keating stresses how esprit de corps must be linked with a 'sense of purpose'. ${ }^{12}$ This realistic approach to army relationships was expressed much earlier by the New Zealand Army in a paper that was the product of a questionnaire sent to senior officers. The paper discusses 'the motives for risking life', stressing, among other things, 'the team spirit'. ${ }^{113}$ Thus, there are instrumental reasons for building supportive human relationships on the basis of trust. Whether the relationships amongst New Zealand men were exceptional in any way, exhibiting camaraderie across the ranks, is arguable: 'The consensus among ex-soldiers is that there was a close relationship between officers, NCOs and their men in World War II, which enhanced battle efficiency and discipline. There is disagreement, however, over how close they were. Some assert that officers were just "one of the boys", whereas others take a more pragmatic view, contending that for much of the war there was "free mixing", but distances between ranks remained. ${ }^{114}$

Mateship certainly existed beyond formal military organisational units in that men met up with their mates and fraternised with them. Pre-war bonds were strong and extended across ranks. The McLeay letters provide further evidence for the importance of these linkages, relationships that were reinforced through the letters home. Roger McElwain writes that, in a small society such as New Zealand, with battalions recruited from particular areas, it was probable that local bonds were transferred to the men serving overseas. ${ }^{115} \mathrm{He}$ also suggests that, although the sense of family was vital to success, perhaps the bonds could work against efficiency and effectiveness, with incompetent leadership being treated with tolerance by senior officers. ${ }^{116}$ A further disadvantage might be that local bonds could lead to unco-operative behaviour through provincial rivalry, ${ }^{117}$ although there is no suggestion of this in the McLeay letters. Phillips, on the other hand, says that the geographical ties meant that social control could be effective. ${ }^{118}$ Certainly, there were many stories about friends included in the McLeay letters that could be circulated by others at home, with possible consequences ensuing. However, undoubtedly there was a degree of social self-censorship in all soldiers' letters to home, including those written by Rod McLeay: not everything was suitable for partner, family and friends. 
There is a further point, however, that should warn analysts to be cautious about assuming mateship from reading the words written by soldiers. The 'getting on with others' behavioural norm, part of the culture of most institutions, whether these are places of work or leisure organisations, is easily communicated in vernacular language. Expressions of this norm may thus partake more of the vocabulary of mateship than of its ethos. Perhaps Rod's use of terms such as 'the blokes' and 'the lads', and his occasional drinking with them, should be interpreted with caution. Further, Rod was writing as an officer: his men might have seen things rather differently.

Jock Phillip's interpretation of mateship adds a second ingredient to the concept: mateship was rather more than camaraderie, in that it was wound up with New Zealand men's uneasy relationships with women and families. ${ }^{119}$ The letters studied by Montgomerie and the McLeay letters, albeit providing limited evidence, reveal a rather more comfortable fit between masculinity and domesticity than that portrayed by Phillips. ${ }^{120}$ Rod McLeay, like the letter writers studied by Montgomerie, constantly referred to the longing for home and domestic life with Molly. His letters showed his ready acceptance of men's companionship and comradeship, but this was simply making the best of a temporary situation: 'It is now nearly two years since I went into camp and they are the longest two years I have ever spent. Fortunately wars CANNOT last for ever, and I suppose that if we are patient the time will eventually arrive when peace is declared.' ${ }^{121}$

The third ingredient of mateship seems to be a certain tolerance of larrikin behaviour. What exactly does 'larrikin' mean? The studies of New Zealand soldiers in the two world wars stress two characteristics of larrikinism. The first is that, partly because they were civilians who saw themselves as 'short-term soldiers ... they had neither the inclination nor the patience to accept some of the more regimented aspects of the discipline of regular soldiering'. ${ }^{122}$ There is much evidence in the literature on New Zealanders during the two world wars to support this point; and the dislike for formal displays of discipline is a norm that dovetails neatly with the 'larrikin' image. Second, larrikinism can refer to drunkenness, disorderly behaviour and theft. Certainly, Rod tolerated, and actively involved himself in, a certain amount of drinking and minor theft - not to do so would have harmed his relationship with his men, and he took overt pleasure in some of these activities. One wonders, though, whether exactly the same or worse behaviour might be found in most wartime situations. Further, larrikinism is not necessarily the same as mateship and may not be an indication of it: these behavioural traits can exist independently of one another.

Finally, I wish to leave to one side the contested issues of the nature of the culture of the New Zealand Army discussed above and note a further theme that comes through the letters written by Rod McLeay. This recurring 
theme is the writer's personal sense of what he owed his men, his Battalion, the Army, his country, and of course his wife and family - his sense of duty. Heeding duty did not include an uncritical acceptance of army life and its rules, as this analysis has shown. Nonetheless, the letters display an attitude to leadership responsibility and service that may or may not be atypical of a serving officer. Rod's notion of duty underlined his perceptions of his roles and relationships. It might be that ideas about duty and responsibility deserve more discussion and analysis in studies of army culture. In a recent article analysing feminist views of the contemporary United States military and the notion of it as 'hyper-masculine', the author writes: 'What the proponents of the macho military either fail to understand (or do not make sufficiently clear) is that it is not aggression, but the ability to doggedly stand one's ground, obey orders, and remain loyal to one's fellows that creates effective military forces. ${ }^{123}$

The last words, however, should come from Rod McLeay. In a passage that appropriately links letter-writing with his views on duty, he wrote: 'Mail day is the BIG day in army life, as none of us really enjoys soldiering and no normal person would, but after all, it is a means to ensure that the ones we love are safe, no matter what the cost. That is one thing I have a deep admiration for in the N.Z. soldier, his wish to go home, but with a determination not to do so until this business is over.' ${ }^{124}$ Later that year, after writing about how he had given up hope of his brother surviving the sinking of his hospital ship and expressing his sadness at Ken McLeay's death, Rod said: 'Still, war and all its sorrows is with us and we must face up bravely to whatever may come our way.' ${ }^{\prime 25}$

1 This article was originally presented at the seminar 'War and Remembrance', organised by the Faculty of Humanities and Social Sciences, Victoria University of Wellington, 2 May 2008. I would like to thank the organisers, Matthew Trundle and James Belich, for giving me the opportunity to contribute. I wish also to express my gratitude to Pete Connor, who made sure that I read the right books and papers, lent me materials and provided me with an informed commentary on New Zealand military history. Many thanks also to Joseph Dowrick, who corrected my military terminology; to Charles Watson, who helped Rod McLeay locate some of his records; and to the two anonymous referees for their helpful comments. Most of all I wish to thank my mother, Molly McLeay, and my sisters, Noeline Pannett, Maggie Jenns and Sally McLeay, for permitting me to write about Rod McLeay's letters.

2 Jock Phillips, A Man's Country? The Image of the Pakeha Male: A History, Auckland, 1987, pp.172-9.

3 Glyn Harper, 'A New Zealand Way of War and a New Zealand Style of Command?' in Glyn Harper and Joel Hayward, eds, Born to Lead? Portraits of New Zealand Commanders, Auckland, 2003, pp.27-38.

4 Roger McElwain, 'Commanding Officers of the Infantry Battalions of 2nd New Zealand Division', in Harper and Hayward, p.182. 


\section{Journal of New Zealand Studies}

5 See John McLeod, Myth and Reality: The New Zealand Soldier in World War II, Auckland, 1986.

6 Phillips, pp.179-91, 206-7.

7 Ibid., pp.189-91, 212-16.

8 Ibid., pp.208-11.

9 There are 70 letters in the McLeay Letters collection, from early September 1940 (the first being undated) to 27 April 1942, comprising just under 47,000 words. Many of the letters are in diary format. Rod kept an actual diary for some months during 1940. In January 1941 he switched to recording his diary in his letters.

10 Harper, p.31.

11 Phillips, especially pp.144-6 and 199-205.

12 Harper, p.32.

13 Jane Elliott, Using Narrative in Social Research, London and Thousand Oaks, Ca., 2005, p.149. My analysis is also inevitably influenced by the fact that I am interpreting the letters as a daughter of the writer and recipient.

14 See Deborah Montgomerie, Love in Time of War: Letter Writing in the Second World War, Auckland, 2005, especially pp.1-19.

15 McLeay to McLeay, 6 November 1940, McLeay papers (in author's possession). Molly's letters to her husband have been lost. The punctuation in the extracts used in this paper is the same as in the letters typed by Molly - the originals no longer exist. The very few spelling errors have been corrected. The square brackets contain my explanations. In the quotations from the letters I have used the initials of most of the people Rod mentions but provided the names of well known senior officers. The language used by Rod has not been 'sanitised' in any way.

16 Mary (Molly) McLeay, born on 13 June 1916, was the youngest child of John and Arminel Treneman. John Treneman had a small business in Havelock North, a garage.

17 McLeod, p.157.

18 McLeay, September 1940.

19 Lieut.Gen. Sir Edward Puttick, 25 Battalion, (Official History of New Zealand in the Second World War 1939-45), Wellington, 1960, p.7.

20 James Belich, 'Paradise Reforged': A History of the New Zealanders from the 1880s to the Year 2000, Auckland, 2001, p.274; and see Peter Ewer, Forgotten ANZACS: The Campaign in Greece, Carlton, Vic., 2008.

21 McLeod, p.68; and Puttick, p.89.

22 Laurie Barber, War Memorial: A Chronology of New Zealand and World War II, Auckland, 1989, p.109; McLeod, pp.45-6; and McElwain, p.188.

23 McLeay to McLeay, 4 November 1941. In that letter Rod commented that 'I will make quite a good concrete mixer when I return - just feed me some sand etc. and I'll do the rest'.

24 Personal communication, Molly McLeay, April 2008.

25 McLeay to McLeay, 3 March 1941.

26 Montgomerie, p.5.

27 McLeay to McLeay, 22 April 1941. The emphases in the quotations, italicised here, were marked by underlining in the typed letters, although sometimes Rod McLeay used capital letters.

28 McLeay to McLeay, 11 January 1941.

29 McLeay to McLeay, 11 November 1941. 


\section{A Wonderful Lot of Chaps}

30 As well as taking numerous photographs of fellow officers, camp scenes and tourist spots, Rod McLeay's photo albums include many pictures of the men in his platoons.

31 McLeay to McLeay, 26 December 1940.

32 The poem was as follows: 'Xmas Greetings from the Boys of old Fifteen. Santa Claus has been because / Mr. Mcleay, we love to play, / And it would seem. / To show our esteem. / A very pleasant way'.

33 McLeay to McLeay, 2 January 1941.

34 McLeay to McLeay, 1 December 1940.

35 See John Crawford, 'Major General Sir Harold Barrowclough: Leadership and Command in Two World Wars', Harper and Hayward, eds, pp.144-63.

36 McLeay to McLeay, 18 January 1942; and see McElwain, p.108.

37 McElwain, pp.189-91.

38 See McLeod, p.66.

39 McElwain, p.179.

40 Montgomerie, p.35.

41 Personal communication, Molly McLeay, August 2008.

42 McLeay to McLeay, 6 November 1940.

43 McLeay to McLeay, 21 August 1941.

44 McLeay to McLeay, 13 July 1941.

45 McLeay to McLeay, 4 November 1941. 'Mag' means 'a talk, chat, a chatterer'. 'Mag', Dictionary of New Zealand English, Auckland, 1997, p.459.

46 McLeay to McLeay, 17 February 1941.

47 McLeay to McLeay, 24 October, 1941.

48 Sgt. Kenneth Andrew McLeay, MM (for gallantry in Crete): born 22 May 1918, wounded November 1941, died when the Chakdina was torpedoed on 5 December 1941 on its trip from Tripoli to Alexandria with New Zealand wounded (among others) on board. Ken McLeay was a gunner in the 2nd New Zealand Divisional Artillery. See D.M. Davin, Crete, (Official History of New Zealand in the Second World War 1939-45), Wellington, 1953, pp.130 and 227; W. E. Murphy, 2nd New Zealand Divisional Artillery, (Official History of New Zealand in the Second World War 1939-45), Wellington, 1966, pp.119-20, 133, 136, and 290. In his letter home, Rod described how Ken's vehicle was mined, injuring him 'although not badly' (27 December 1941).

49 McLeay to McLeay, 27 December 1941.

50 McLeay to McLeay, 14 November 1940.

51 McLeay to McLeay, 19 December 1940.

52 McLeay to McLeay, 2 January 1941.

53 McLeay to McLeay, 5 January 1941.

54 McLeay to McLeay, 2 January 1941.

55 McLeay to McLeay, 4 October 1940.

56 Pete Connor, 'Finding Ways to Survive: 24 (Auckland) Battalion and the Experiential Learning Curve', M.Phil thesis, Massey University, pp.47-9; and see Puttick, pp.5268.

57 McLeay, note on Molos, 1941, in author's possession. See McLeod on the importance of keeping soldiers fully informed, p.69.

58 McLeay, note on Molos, 1941.

59 McLeay, personal communication. 


\section{Journal of New Zealand Studies}

60 McLeod, p.31.

61 See Connor, p.152.

62 Phillips, p.211.

63 McLeay to McLeay, 24 February 1941.

64 Connor, p.28; and see Phillips, p.208.

65 McLeay to McLeay, 19 November 1940.

66 See Phillips, pp.209-10.

67 McLeay to McLeay, 13 August 1941. Puttick writes that 'the rate of unloading was twice that achieved by the usual dock labour and the rate of ullage and pillage was considerably less. It is understood that the pillage that did occur included American canned beer and silk stockings. . ., p.82.

68 New Zealand Army, Infantry in Battle: Notes on the Training and Command of New Zealand Infantry Units, Wellington, 1949, s.36; and see McLeod, p.168.

69 McLeay to McLeay, 7 December 1940.

70 McLeay to McLeay, 13 October 1940.

71 McLeay to McLeay, 21 April 1941.

72 McLeay to McLeay, 4 May 1941.

73 McLeay to McLeay, 3 September 1940.

74 McLeay to McLeay, 3 July 1941.

75 McLeay to McLeay, 2 June 1941.

76 McLeay to McLeay, 18 January 1942.

77 McLeay to McLeay, 11 April 1941.

78 McLeay to McLeay, 27 April 1942.

79 McLeay to McLeay, 27 April 1942.

80 McLeay to McLeay, 2 January 1941.

81 McLeay to McLeay, 1 December 1940.

82 McLeay to McLeay, 3 February 1941.

83 Gavin Keating, A Tale of Three Battalions: Combat Morale and Battle Fatigue in the 7th Australian Infantry Brigade, Bougainville, 1944-5, Canberra, 2007, pp.12, 61.

84 McLeay to McLeay, 6 November 1940.

85 McLeay to McLeay, 19 December 1940.

86 McLeay to McLeay, 5 January 1941.

87 McLeay to McLeay, 12 January 1941.

88 McLeay to McLeay, 3 February 1941.

89 McLeay to McLeay, 17 February 1941.

90 McLeay to McLeay, 13 July 1941.

91 McLeay to McLeay, 13 August 1941.

92 McLeay to McLeay, 21 August 1941.

93 McLeay to McLeay, 27 August 1941.

94 McLeay to McLeay, 8 September 1941.

95 McLeay to McLeay, 15 September 1941.

96 McLeay to McLeay, 4 October 1941.

97 McLeay to McLeay, 16 October 1941. Belich writes that the NZ Army made promotions and demotions 'without much regard for HQ in Wellington', p. 279.

98 McLeay to McLeay, 4 November 1941. 


\section{A Wonderful Lot of Chaps}

99 McLeay to McLeay, 11 November 1941.

100 McLeay to McLeay, 27 December 1941.

101 McLeay to McLeay, 9 February 1942.

102 McLeay to McLeay, 18 March 1942.

103 McLeay to McLeay, 24 April 1942.

104 J. Soefters and R. Recht, 'Culture and Discipline in Military Academies: An International Comparison', Journal of Political and Military Sociology (JPMS), 26, 2 (1998), p.182; and see Joseph Soeters, 'Value Orientations in Military Academies: A Thirteen Country Study', Armed Forces and Society (AFS), 24, 1 (1997), pp.7-32. The New Zealand Army was not included in the surveys.

105 Phillips, p.146.

106 See Belich, p.278; and Phillips, pp.147-8.

107 Belich suggests that New Zealanders, more than the British, might have been ideologically 'comfortable with egalitarianism', as the process of democratisation of the officer class proceeded throughout the war years, with an increasing number of junior officers being promoted from the ranks, p.278; and McLeod, pp.156-7.

108 Phillips, p.159.

109 Ibid., p.163.

110 Montgomerie, p.133.

111 On this point, see Regina F. Titunik, 'The Myth of the Macho Military', Polity, 40, 2 (2008), p.147.

112 Keating, p.12.

113 New Zealand Army, s.7, and see also s.22.

114 McLeod, p.165.

115 McElwain, pp.189-91; and see the similar comments in New Zealand Army, s.22.

116 McElwain, pp. 190-91.

117 McLeod, p.66.

118 Phillips, p.171.

119 Ibid., pp. 189-91 and 212-16.

120 On this point see Montgomerie, p.134.

121 McLeay to McLeay, 19 February 1942.

122 McLeod, p.120.

123 Titunik, p.148.

124 McLeay to McLeay, 24 October 1941.

125 McLeay to McLeay, 27 December 1941. 
Journal of New Zealand Studies 